\title{
Evaluation of antioxidant activity of agro-industrial waste of acerola (Malpighia emarginata D.C.) fruit extracts
}

\author{
Avaliação da atividade antioxidante de extratos de resíduo agroindustrial \\ de acerola (Malpighia emarginata D.C.)
}

Ana Carla da Silva CAETANO ${ }^{1}$, Cristiane Rodrigues de ARAÚJO², Vera Lúcia Arroxelas Galvão de LIMA , Maria Inês Sucupira MACIEL ${ }^{1}$, Enayde de Almeida MELO ${ }^{1 *}$

\begin{abstract}
This study was carried out to evaluate the antioxidant capacity of the agro-industrial waste from acerola. Hydroacetone, hydroethanolic, and hydromethanolic extracts were obtained using the sequential extraction process, and they were screened for their free radical DPPH ${ }^{\circ}$ (1,1-diphenyl-2-picrilhidrazil) and ABTS ${ }^{+}\left(2,2^{\prime}\right.$-azino-bis-(3-etilbenzotiazolin 6-sulfonic acid) scavenging activity and their effect on the linoleic acid peroxidation by the ferric thiocyanate method. Soybean oil with the addition of the extracts (200 ppm) was submitted to Schaal oven test $\left(60^{\circ} \mathrm{C}, 28\right.$ days), in which the samples were analyzed for peroxide value and conjugated dienes. Hydroethanolic and hydromethanolic extracts exhibited good DPPH scavenging activity (low value of $\mathrm{EC}_{50}$ and $\mathrm{T}_{\mathrm{EC} 50}$ and high value of $\mathrm{AE}$ ), good ABTS scavenging capacity (1445.1 and $1145.5 \mu \mathrm{Mol}$ TEAC. ${ }^{-1}$, respectively), and high percentage inhibition of peroxidation of linoleic acid ( 96.12 and $91.84 \%$, respectively) and showed the ability to retard the formation of peroxides and conjugated dienes.

Keywords: antioxidant; $\mathrm{DPPH} ; \mathrm{ABTS}^{+}$; ferric thiocyanate; peroxide value; conjugated dienes; acerola fruit waste.
\end{abstract}

\section{Resumo}

Com o objetivo de avaliar a capacidade antioxidante de resíduo agroindustrial de acerola, extratos hidroacetônico, hidroetanólico e hidrometanólico, obtidos por processo de extração sequencial, foram submetidos à determinação do teor de fenólicos totais e da atividade antioxidante em sistema modelo e em óleo de soja. A capacidade dos extratos de sequestrar os radicais DPPH• (1,1-difenil-2-picrilhidrazil) e $\mathrm{ABTS}^{*+}$ (2,2'-azino-bis-(3-etilbenzotiazolina-6-ácido sulfônico), e de inibir a peroxidação do ácido linoleico pelo método tiocianato férrico foi avaliada. Para o teste acelerado em estufa, o óleo acrescido dos extratos ( $200 \mathrm{ppm})$ foi incubado a $60{ }^{\circ} \mathrm{C}$ durante 28 dias e, em intervalos regulares de tempo, foram determinados os índices de peróxido e de dienos conjugados. Os extratos hidroetanólico e hidrometanólico exibiram forte capacidade de sequestro do radical $\mathrm{DPPH}^{\bullet}$ (baixo valor de $\mathrm{EC}_{50}$ e de $\mathrm{T}_{\mathrm{EC} 50 \text {, }}$ alta EA), elevada capacidade de sequestro do radical $\mathrm{ABTS}^{++}(1.445,1$ e 1.145,5 $\mu \mathrm{Mol} \mathrm{TEAC} / \mathrm{g}$, respectivamente) e elevado percentual de inibição da peroxidação do ácido linoleico ( 96,12 e $91,84 \%$, respectivamente). Estes extratos, também, apresentaram capacidade em retardar a formação de peróxidos e de dienos conjugados. Palavras-chave: antioxidante; $\mathrm{DPPH}{ }^{*}$ : $\mathrm{ABTS}^{\circ}$; tiocianato férrico; índice de peróxido; dienos conjugados; resíduo de acerola.

\section{Introduction}

The lipids are recognized as important nutrients to our diet. They provide essential fatty acids and energy to the body and the proper absorption of fat-soluble vitamins. Due to their chemical nature, these molecules are subject to the oxidation reactions that promote change of taste and smell and the nutritional value of foods. Therefore, the lipid oxidation is an auto-catalytic process since the initial products of the reaction flavor chain propagation must be avoided in order to minimize adverse effects and increase the shelf life of food products (KRING; BERGER, 2001).

The food industry has been using synthetic antioxidant additives, alone or in combinations, in order to protect lipids from oxidative degradation. The most used ones are butylated hydroxy anisole (BHA), butylated hydroxy toluene (BHT), tert-butyl hydroquinone (t-BHQ), and propyl gallate (PG). Their safety, however, has been questioned, and in many countries where the government established the regulation for the use of additives, which have been suspected to cause or promote negative health effects, they have been banned (YILDRIM et al., 2001). Hence, in the early 80's, the search for natural antioxidants was greatly emphasized and several natural sources have been examined. Many phytochemicals that are antioxidants, especially phenolic compounds, have been isolated from extracts of different parts of plants, such as seeds, fruits, leaves, stems, and roots (MALECKA, 2002; SCHMIDT et al., 2003). Interestingly, the seeds and peel of some fruits may potentially contain higher amounts of phenolic compounds than

${ }^{1}$ Home Economic Department, Food Science and Technology Post graduation Program - PGCTA, Federal Rural University of Pernambuco - UFRPE,

Av. Dom Manoel de Medeiros, s/n, CEP 52171-900, Recife, PE, Brazil

${ }^{2}$ Graduate School of Home Economic, Federal Rural University of Pernambuco - UFRPE, Av. Dom Manoel de Medeiros, s/n, CEP 52171-900, Recife, PE, Brazil

${ }^{*}$ Corresponding author 
the pulp fractions. In general, the profile of phytochemicals on these parts of the plants is different (GUO et al., 2003).

Another important aspect is the high volume of agro-industrial waste produced in Brazil due to its very high agricultural activity. The acerola fruit industry, for instance, processes 34.40 thousand tons, the equivalent to $7.16 \%$ of the total processed fruit, producing 18 thousand tons of juice and pulp. As a consequence, a great quantity of waste is generated: organic material with no commercial value that often becomes a source of environmental pollution. In many research centers, there has been growing efforts to find alternative uses for the organic material generated by the agriculture industry (CATANEO et al., 2008). The use of vegetable waste to extract bioactive compounds that could be used in the food, pharmaceutical, and cosmetics industry would be an effective low cost option that would also lessen their environmental impact (MAKRIS; BOSKOU; ANDRIKOPOULOS, 2007). In addition to that, it would be a viable alternative to explore antioxidant composites of the waste from the tropical fruits juice processing (OLIVEIRA et al., 2009).

Therefore, considering that a great amount of phenolic compounds with considerable antioxidant properties can be found in acerola fruit agro-industrial waste, and also that the processing of this fruit generates a great amount of waste, this research project aimed at investigating the antioxidant capacity of these materials focusing on exploring their lipid oxidation inhibiting potential.

\section{Materials and methods}

\subsection{Sample preparation}

The acerola fruit waste (peels and seeds) was kindly provided by the FRUTOTAL, a company that produces frozen fruit pulp and which is located in the city of Recife-Brazil. At the Physical-Chemical Analysis Laboratory of the Home Economic Department of the Federal Rural University of Pernambuco (UFRPE), the samples were dried in an oven with air circulation at $50^{\circ} \mathrm{C}$ (Marconi) until they reached moisture content of $10 \%$ or less. The dehydrated waste was crushed using a multiprocessor (Tecnal) and passed through a 80 mesh sieve; the powder was stored in polyethylene bags and maintained at the temperature of $-18^{\circ} \mathrm{C}$ until its analysis.

\subsection{Extraction}

The hydroacetone, hydroethanolic, and hydromethanolic extracts were obtained using the sequential extraction method at room temperature $\left(25 \pm 2{ }^{\circ} \mathrm{C}\right)$. The acerola fruit waste powder $(5 \mathrm{~g})$ was kept under continuous shaking in $80 \%$ acetone $(30 \mathrm{~mL})$ for 20 minutes, and then it was filtered through filter paper. The residue was again submitted to two more extraction cycles of 20 minutes each totalizing 60 minutes of extraction time. The filtrate was combined in volumetric flasks, and the volume was made up to $100 \mathrm{~mL}$. This procedure was repeated with $80 \%$ ethanol and $80 \%$ methanol. The extracts were stored in a freezer at $-18{ }^{\circ} \mathrm{C}$ until assayed. The extraction was performed in triplicate.

\subsection{Determination of total phenolic contents}

The concentration of total phenolic compounds was determined by spectrophotometry, using the Folin-Ciocalteau reagent (Merck), according to the methodology described by Wettasinghe and Shahidi (1999) and using catechin as standard. The results were expressed as catechin equivalent $(\mu \mathrm{Mol})$ per L of the extract.

\subsection{Antioxidant activity evaluation}

\section{$D P P H \cdot(1,1$-difenil-2-picrilhidrazil) scavenging capacity}

The scavenging activity on DPPH• (1,1-difenil-2picrilhidrazil) free radical of the extracts was determined by the method described by Brand-Williams, Cuvelier and Berset (1995), modified by Sánchez-moreno, Larrauri and Saura-Calixto (1998). Extracts with different total phenolic concentrations were added to the DPPH solution in methanol $(0.1 \mathrm{M})$ reaching a final concentration of 34, 52, and $103 \mu \mathrm{Mol} . \mathrm{L}^{-1}$ total phenolic. The absorbance at $515 \mathrm{mn}$ was measured using the spectrophotometer (Shimadzu UV-1650PC) until the reaction reached a plateau. The concentration of the remaining DPPH in the middle of the reaction was calculated based on the standard curve of the DPPH radical. The percentage of the remaining DPPH $\left(\% \mathrm{DPPH}_{\mathrm{rem}}\right)$ of each extract concentration was calculated using the following Equation 1:

$\% \mathrm{DPPH}_{\mathrm{REM}}=\left(\mathrm{DPPH}_{\mathrm{t}} / \mathrm{DPPH}_{\mathrm{T}=0}\right) \times 100$

where: $\mathrm{DPPH}_{\mathrm{t}}$ is the $\mathrm{DPPH}$ radical concentration at the time of steady state; $\mathrm{DPPH}_{\mathrm{T}=0}$ is the initial concentration of $\mathrm{DPPH}$ (at the time of zero).

The concentration of antioxidant concentration required to cause a $50 \%$ decrease in the initial DPPH concentration $\left(\mathrm{EC}_{50}\right.$ ) was calculated by plotting \% $\mathrm{DPPH}_{\mathrm{REM}}$ against the sample concentration (sample's total phenolic). The results were expressed as extract phenolic $(\mu \mathrm{Mol}) \mathrm{DPPH} . \mu \mathrm{Mol}^{-1}$. The time needed to reach the steady state to $\mathrm{EC}_{50}$ concentration $\left(\mathrm{T}_{\mathrm{EC} 50}\right)$ was calculated graphically. The antiradical efficiency (AE) was calculated considering the $\mathrm{EC}_{50}$ value and the necessary time to reach the $\mathrm{EC}_{50}\left(\mathrm{~T}_{\mathrm{EC} 50}\right)$, according to the following Equation 2:

$\mathrm{AE}=1 / \mathrm{EC}_{50} \cdot \mathrm{T}_{\mathrm{ECS} 0}$

The BHT and ascorbic acid DPPH $\cdot$ radical scavenging capacity were included for comparative purposes.

ABTS $^{++}$(2,2'-azino-bis (3-ethylbenzthiazoline-6-sulphonic acid) radical scavenging capacity

The 2,2'-azino-bis(3-ethylbenzthiazoline-6-sulphonic acid $\left(\mathrm{ABTS}^{*+}\right)$ radical scavenging capacity was determined according to the method described by RE et al. (1999). The ABTS ${ }^{+}$was produced by reacting ABTS aqueous solution $(7 \mathrm{mM})$ with $2.45 \mathrm{mM}$ potassium persulfate (final concentration) and allowing the mixture to stand in the dark at room temperature for 16 hours before use. Prior to assay, the solution was diluted in ethanol to an absorbance of $0.7 \pm 0.05$ at $734 \mathrm{~nm}$. Next, the extracts with different total phenolic concentrations were added to the $\mathrm{ABTS}^{*+}$ solution reaching the final concentration of 10,15 , 
and $30 \mu \mathrm{g}$, and after 6 minutes, the absorbance was measured using a spectrophotometer (Shimadzu UV-1650PC). The antioxidant capacity of the sample was calculated in relation to the activity of the synthetic antioxidant Trolox (6-hydroxy-2.5, 7, 8-tetramethylchroman-2-carboxylic acid) under the same conditions. The results were expressed as antioxidant activity equivalent to the Trolox ( $\mu$ Mol TEAC. $g^{-1}$ of the extract total phenolic).

\section{Antioxidant activity in linoleic acid emulsion}

The antioxidant activity of the extracts was determined using the Thiocyanate Method described by Jayaprakasha, Singh and Sakariah (2001). The linoleic acid emulsion was prepared by homogenizing $0.28 \mathrm{~g}$ of linoleic acid, 0.28 of Tween 20 as the emulsifier, and $50 \mathrm{~mL}$ of phosphate buffer $0.2 \mathrm{M} \mathrm{(pH} \mathrm{7.0).} \mathrm{The}$ extracts were individually mixed with $2.5 \mathrm{~mL}$ of the linoleic acid emulsion and $2.5 \mathrm{~mL}$ phosphate buffer $0.2 \mathrm{M}(\mathrm{pH} 7.0)$ reaching a final concentration of $125 \mathrm{ppm}$ of the total phenolic, stored in screw-capped amber flask, and incubated at $50{ }^{\circ} \mathrm{C} \pm 0.5$ in an oven with air circulation. In regular periods (every 2 days), $0.1 \mathrm{~mL}$ of this solution was taken out and added to $5 \mathrm{~mL}$ of $75 \%$ ethanol $(\mathrm{v} / \mathrm{v}), 0.1 \mathrm{~mL}$ of $30 \%$ ammonium thiocyanate $(\mathrm{w} / \mathrm{v})$, and $0.1 \mathrm{~mL}$ of ferrous chloride $0.02 \mathrm{M}$ in $3.5 \% \mathrm{HCl}$. After exactly 3 minutes at room temperature $\left(25.0 \pm 0.5^{\circ} \mathrm{C}\right)$, the absorbance at $500 \mathrm{~nm}$ was measured using a Shimadzu UV-1650PC spectrophotometer. The experiment was complete when the control sample (without any addition of antioxidant) reached a maximum rate of absorbance. The degree of linoleic acid peroxidation inhibition was calculated using the following Equation 3:

Inhibition $\%=100-\left(\frac{\text { Increase in absorbance of sample }}{\text { Increase in absorbance of control }}\right) \times 100$

Samples with the addition of BHT (100 ppm) and ascorbic acid (100 ppm) were prepared for comparative purposes.

\section{Antioxidant activity in soybean oil (Schaal oven test): rate of peroxides and conjugated dienes}

Refined soybean oil $(50 \mathrm{~mL})$ free of synthetic antioxidant and citric acid, provided by Bunge Alimentos S.A. (Recife-PE, Brazil), was used as substrates for oxidation studies. The extracts were individually added to oil into screw-capped amber flasks reaching the final concentration of $200 \mathrm{ppm}$ of the total phenolic. To incorporate the extracts, Tween 20 emulsifier was added to the oil. Control samples without the addition of any extract and with BHT (200 ppm) and ascorbic acid (200 ppm) were prepared for comparative purposes. Control and test samples were incubated in an oven at $60^{\circ} \mathrm{C}$ for 28 days. Samples were taken out at different intervals $(0,7,14,21$, and 28 days), the peroxide value was measured by the iodometric titration procedure according to the method (Cd 8-53) from the AOCS (2006), and conjugated diene content was determined using the spectrophotometric method (Ti 1a-64) described at the AOCS (2006). The results were expressed as milliequivalents peroxide per kilogram of oil (meq.peroxide. $\mathrm{kg}^{-1}$ of oil) and conjugated dienoic acid percentage, respectively.

\subsection{Statistical analysis}

All determinations were carried out in triplicate, and the data recorded as mean and standard deviation were submitted to variance analysis (ANOVA) followed by Duncan's multiple-range test $(\mathrm{p}<0.05)$, using the software Statistics for Windows version 6.0.

\section{Results and discussion}

The hydroacetone extract had the highest total phenolic contents, which was significantly $(\mathrm{p}<0.05)$ higher than the other extracts (Table 1). Thus, the majority of the phenolic compounds found in acerola fruit agro-industrial waste could be extracted in $80 \%$ acetone.

Solvents extraction using aqueous methanol, ethanol, acetone, propanol, ethyl acetate, and dimethylformamide in various proportions have been commonly used for the extraction of phenolics from fruits and their waste. Alothman, Bhat and Karim (2009) used mixtures of water with ethanol, acetone, or methanol in different concentrations $(50,70$, and $90 \%$ ) and observed that $50 \%$ acetone and $70 \%$ ethanol extracted higher polyphenol content from the pineapple while in guava, the highest content of polyphenols was obtained with $90 \%$ acetone and $90 \%$ ethanol. The total phenolic content of acetone extract of waste of grapes of COUDERC13 and Pinot Gris varieties ranged from 109.64 to 207.80 and from 370.17 to $420.61 \mathrm{mg}$ of gallic acid $100^{-1} \mathrm{~g}$, respectively (CATANEO et al., 2008). A smaller level was found in $60 \%$ methanol extract of mango seeds and peel (RIBEIRO et al., 2008).

Solvent polarity plays a key role in increasing phenolic solubility (NACZK; SHAHIDI, 2006). The solubility of these constituents in a specific solvent is a peculiar characteristic of the phytochemical, which explains the inexistence of a universal procedure and demonstrates the need for a meticulous selection of the extraction method for each natural source of antioxidants. Usually, the least polar solvents are considered to be more suitable for the extraction of lipophilic polyphenols. On the other hand, aqueous acetone mixtures are good solvent systems for the extraction of polar phytochemicals. Aqueous ethanol mixtures are commonly used for the extraction of phenolics from plant materials. This is due to wide range of phenolic compounds that aqueous ethanol mixtures can dissolve. Furthermore, hydroethanolic solvents have acceptability for human consumption models (ALOTHMAN; BHAT; KARIM, 2009).

Table 1. Total phenolic contents ( $\mu \mathrm{Mol}$ catequin equivalent. $\mathrm{L}^{-1}$ ) in acerola fruit agro-industrial waste extracts.

\begin{tabular}{ccc}
\hline \multicolumn{3}{c}{ Total phenolic $\left(\mu\right.$ Mol catequin equivalent. $\left.\mathrm{L}^{-1}\right)$} \\
\hline $\begin{array}{c}\text { Hydroacetone } \\
\text { extract }\end{array}$ & $\begin{array}{c}\text { Hydroethanolic } \\
\text { extract }\end{array}$ & $\begin{array}{c}\text { Hydromethanolic } \\
\text { extract }\end{array}$ \\
\hline $20531.7 \pm 304.5^{\mathrm{a}}$ & $6140.0 \pm 179.2^{\mathrm{b}}$ & $4856.5 \pm 238.73^{\mathrm{b}}$ \\
\hline $\begin{array}{l}\text { The data are expressed as mean } \pm \text { standard deviation }(\mathrm{n}=3) . \\
\text { letters are significantly different at } \mathrm{p}<0.05 .\end{array}$
\end{tabular}




\subsection{Antioxidant activity}

\section{DPPH radical scavenging}

The $\mathrm{EC}_{50}$ value is inversely correlated with the antiradical activity. Consequently, the extracts with high free radicals scavenging potential have a low $\mathrm{EC}_{50}$ value (ROESLER et al., 2007). Thus, the hydroethanolic and hydromethanolic extracts with the lowest $\mathrm{EC}_{50}$ values showed a better DPPH radical scavenging capacity, whose activity was statistically similar to that of the ascorbic acid. The hydroacetone extract showed the lowest antioxidant activity even though it was not significantly different from the BHT's (Table 2). Samotyja and Malecka (2007) observed high free radical scavenging potential in commercial rosemary extracts water soluble, commercial rosemary extracts oil soluble, and blackcurrant seeds ethanolic extract. These extracts with $\mathrm{EC}_{50}$ values of 0.106, 0.143, and $0.103 \mathrm{~g}$ of antioxidant $/ \mathrm{g}$ DPPH ${ }^{\circ}$ and an antiradical effectiveness of $0.45 \times 10^{-3} ; 0.25 \times 10^{-3}$ and $0.35 \times 10^{-3}$, respectively, showed comparable antiradical potential.

Considering that the antioxidant power results from the capacity of the compound or extract to prevent the oxidation of the substrate in low concentration, preventing or retarding autoxidation reaction, the use of other parameters, in addition to $\mathrm{EC}_{50}$, is necessary in order to better evaluate the antioxidant capacity of a sample. Accordingly, Sánchez-moreno, Larrauri and Saura-Calixto (1998) established the $\mathrm{T}_{\mathrm{EC} 50}$ and EA as antioxidant capacity evaluation parameters in DPPH assay. According to these authors, the antioxidant kinetic behavior, taking the $\mathrm{T}_{\mathrm{EC} 50}$ value as a reference, can be classified as fast ( $\mathrm{T}_{\mathrm{EC} 50}$ $<5$ minutes), intermediate ( $\mathrm{T}_{\mathrm{EC} 50}=5$ to 30 minutes), or slow $\left(\mathrm{T}_{\mathrm{EC} 50}>30\right.$ minutes) and, regarding the antiradical efficiency (AE) which involves $\mathrm{EC}_{50}$ and $\mathrm{T}_{\mathrm{EC} 50 \text {, }}$ the antioxidant can be classified as low $(\mathrm{AE}<1)$, medium ( $\mathrm{AE}>1$ and $\leq 5)$, high ( $\mathrm{AE}$ $>5$ and $\leq 10)$, or very high $(\mathrm{AE}>10)$ radical scavenging capacity.

Taking the classification standards described above on Table 2 as a reference, it is evident that the hydroethanolic extract, similarly to the ascorbic acid, reacted rapidly with the $\mathrm{DPPH}$ radical $\left(\mathrm{T}_{\mathrm{EC} 50}<5\right.$ minutes), while the other extracts were considered as reacting at an intermediate speed $\left(\mathrm{T}_{\mathrm{EC} 50}=5\right.$ to 30 minutes). Regarding the antiradical effectiveness, the hydroethanolic extract and the ascorbic acid $(\mathrm{AE}>5$ and $\leq 10)$ $(\mathrm{AE}>10)$ were classified as highly effective, while the hydromethanolic and the hydroacetone extract, together with the BHT, were included in the low effectiveness category. Therefore, due to the low values of $\mathrm{EC}_{50}$ and $\mathrm{T}_{\mathrm{EC} 50}$ and high value of $\mathrm{AE}$, the hydroethanolic extract, shows a strong antioxidant power over the DPPH radical.

\section{ABTS radical scavenging}

The ABTS ${ }^{*}$ free radical scavenging capacity of the acerola fruit agro-industrial waste extracts are shown in Table 3. All extracts possessed the $\mathrm{ABTS}^{+}$radical scavenging activity but in different degrees. The TEAC values ranged from 159.38 to $1445.1 \mu \mathrm{Mol.g}{ }^{-1}$.

The hydroethanolic extract exhibited the highest scavenging capacity, followed by the hydromethanolic, whose activity was higher than that of hydroacetone extract, BHT, and ascorbic acid. The antioxidant activity of the hydroethanolic and hydromethanolic extracts of the acerola fruit waste showed higher scavenging activity than that of the extracts from the bagasse of two varieties of grape determined by Cataneo et al.

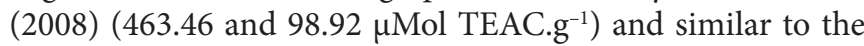
antioxidant activity of the hydromethanolic extract of the mango

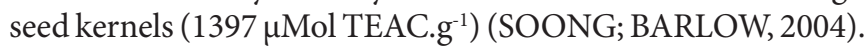
However, the ethanolic fruit peel extracts from eight kinds of fruits commonly consumed and grown in Thailand exhibited the highest TEAC values, ranging widely from $207 \times 10^{-3}$ a $4070 \times 10^{-3} \mu \mathrm{Mol.g}{ }^{-1}$. The extracts of pomegranate peels (Punica granatum) and long-gong peels (Lansium domesticum) presented the highest and lowest antiradical capacity, respectively (OKONOGI et al., 2007).

\section{Antioxidant activity in linoleic acid emulsion}

The antioxidant effect of the extracts from acerola fruit agro-industrial waste on preventing the peroxidation of linoleic acid, measured by thiocyanate method, is shown in Figure 1. The hydroperoxides generated during the linoleic acid oxidation react with ferrous sulphate to form ferric sulphate, and to ferric thiocyanate of blood-red color, which is spectrophotometrically monitored. After the incubation period (288 hours), the maximum optical density (OD) reached by the control sample (without antioxidants) was 1.1, value at which the assay was interrupted since the control sample optical density decreased thereafter. According to Chen et al., (1996), this is due to the lack of linoleic acid in the reaction and the presence of hydroperoxides, which decompose into many secondary oxidation products. Therefore, after the incubation period, the formation of peroxides was stopped due to non-availability of linoleic acid. Also, intermediate products may be converted to

Table 2. $\mathrm{EC}_{50}, \mathrm{~T}_{\mathrm{EC} 50}$, and $\mathrm{AE}$ values and kinetic and antiradical classification of acerola fruit agro-industrial waste extracts.

\begin{tabular}{|c|c|c|c|c|c|}
\hline Extracts & $\begin{array}{c}\mathrm{EC}_{50} \\
\left(\mu \mathrm{Mol} . \mu \mathrm{Mol} \mathrm{DPPH}^{-1}\right)\end{array}$ & $\begin{array}{c}\mathrm{T}_{\mathrm{EC} 50} \\
\text { (minutes) }\end{array}$ & $\begin{array}{c}\text { Kinetic } \\
\text { classification }\end{array}$ & $\mathrm{AE}$ & $\begin{array}{l}\text { Antiradical } \\
\text { classification }\end{array}$ \\
\hline Hydroacetone & $0.33 \pm 0.02^{\mathrm{a}}$ & $8.57 \pm 0.81^{\mathrm{ab}}$ & Intermediate & $0.35^{\mathrm{d}}$ & Low \\
\hline Hydroethanolic & $0.22 \pm 0.01^{\mathrm{b}}$ & $0.8 \pm 0.59^{c}$ & Fast & $5.68^{\mathrm{b}}$ & High \\
\hline Hydromethanolic & $0.23 \pm 0.01^{\mathrm{b}}$ & $5.42 \pm 0.01^{\mathrm{b}}$ & Intermediate & $0.80^{c}$ & Low \\
\hline BHT & $0.45 \pm 0.01^{\mathrm{a}}$ & $18.12 \pm 0.61^{\mathrm{a}}$ & Intermediate & $0.12^{\mathrm{d}}$ & Low \\
\hline Ascorbic acid & $0.27 \pm 0.02^{\mathrm{b}}$ & $0.57 \pm 0.01^{c}$ & Fast & $6.50^{\mathrm{a}}$ & High \\
\hline
\end{tabular}

The data are expressed as mean \pm standard deviation $(n=3)$. The mean with the different letters are significantly different at $\mathrm{p}<0.05$. $\mathrm{T}_{\mathrm{EC} 50}$. Time needed to reach the $\mathrm{EC}_{50}$ value; $\mathrm{AE}=$ antiradical effectiveness $=1 / \mathrm{EC}_{50} \cdot \mathrm{T}_{\mathrm{EC} 50^{\circ}}$ 
Table 3. ABTS *+ free radical scavenging capacity of acerola fruit agro-industrial waste extracts.

\begin{tabular}{lc}
\hline \multicolumn{1}{c}{ Extracts } & Antioxidant activity $\left(\mu\right.$ Mol TEAC. $\left.\mathrm{g}^{-1}\right)$ \\
\hline Hydroacetone & $291.71 \pm 20.90^{\mathrm{b}}$ \\
Hydroethanolic & $1445.10 \pm 73.07^{\mathrm{a}}$ \\
Hydromethanolic & $1145.50 \pm 45.81^{\mathrm{a}}$ \\
BHT & $159.38 \pm 4.76^{\mathrm{b}}$ \\
Ascorbic acid & $564.32 \pm 45.49^{\mathrm{ab}}$ \\
\hline The data are expressed as mean \pm standard deviation $(\mathrm{n}=3)$. The mean with the different \\
letters are significantly different at $\mathrm{p}<0.05$. TEAC $=$ Antioxidant activity in trolox \\
equivalent (6 minutes).
\end{tabular}

stable end-products resulting in the stoppage of oxidation of ferrous sulphate.

The hydroethanolic and hydromethanolic extracts showed the highest antioxidant activity, which exhibited, respectively, 96.12 and $91.84 \%$ inhibition of linoleic acid peroxidation at 288 hours. These values were statistically comparable to those of the hydroacetone extract (90.74\%) and BHT (96.10\%), but they were different from that of ascorbic acid $(68.88 \%)$. The antioxidant activity of the acerola fruit waste hydroethanolic extract was higher than the antioxidant activity of the grape seeds extracts obtained using acetone, methanol, and four different concentrations of ethyl acetate, as reported by Jayaprakasha, Singh and Sakariah (2001). These authors also reported that the highest antioxidant activity was observed with the extract prepared by ethyl acetate and water (17:3), which exhibited $86 \%$ inhibition of linoleic acid peroxidation at 100 hours. Liu and Yao (2007) evaluated the antioxidant activity of barley extracts obtained from different solvents (70\% methanol, $70 \%$ ethanol, and $70 \%$ acetone) and reported that hydroacetone extract exhibited the highest activity.

\section{Antioxidant activity in soybean oil (Schaal oven test)}

\section{Peroxides concentration}

The antioxidant effect of the acerola fruit agro-industrial waste extracts upon the soybean oil oxidation in an oven at $60^{\circ} \mathrm{C}$ is shown in Figure 1. The peroxide concentration increased in all treatments during the incubation period reaching higher levels at the control sample (oil without antioxidant). This may be explained by the development of lipid oxidation primary products (ANGELO; JORGE, 2008).

The hydroethanolic extract was most effective in retarding the oxidation as shown by the lowest peroxide value, which was statistically similar to the hydromethanolic extract activity after 28 days but higher than the hydroacetone extract and synthetic antioxidants activity (BHT). The Brazilian Standards that regulate the adequacy of soybean oil for human consumption (directive 482/99-ANVISA) establish a maximum peroxides concentration of $10 \mathrm{meq} / \mathrm{kg}$. The acerola waste extracts were very effective in retarding the soybean oil oxidation until the $14^{\text {th }}$ day since they were able to keep the peroxides concentration below the maximum level allowed.

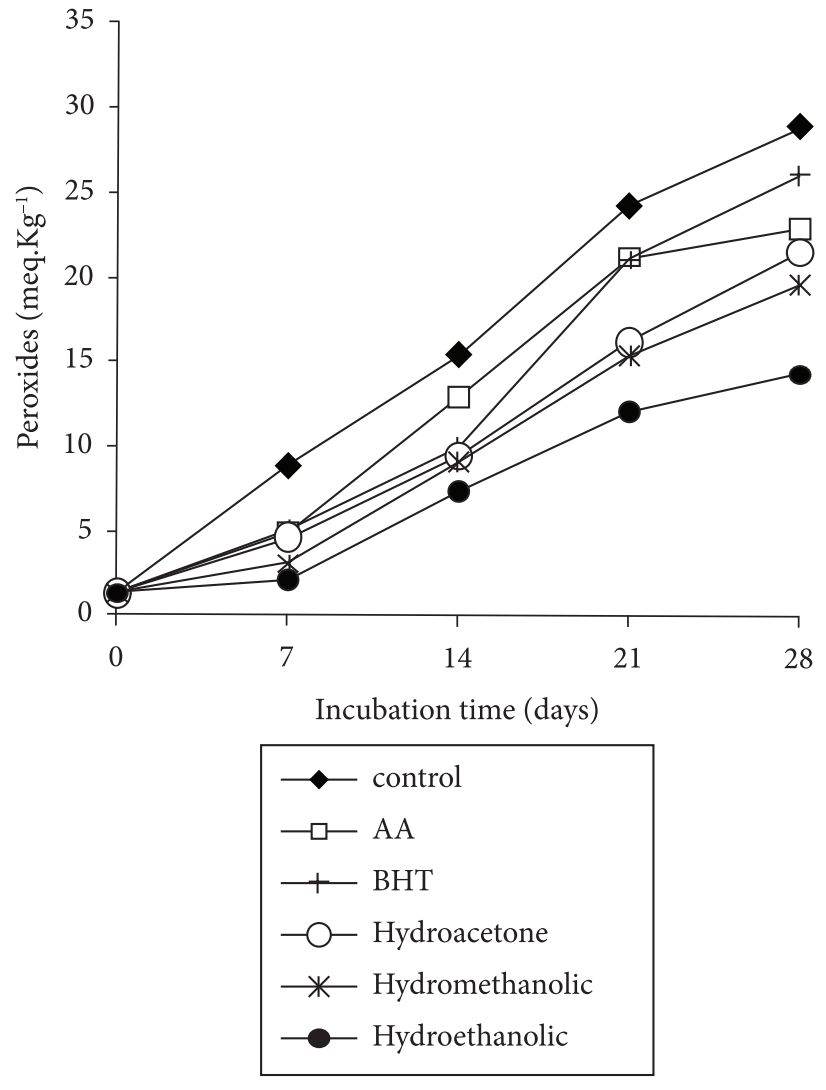

Figure 1. Effect of the addition of acerola fruit waste extract (200 ppm of total phenolic) on the formation of peroxides (meq. $\mathrm{kg}^{-1}$ ) in soybean oil stored at $60^{\circ} \mathrm{C}$ (Schaal oven test) [AA: ascorbic acid; BHT: butylated hydroxyl toluene; control samples: without antioxidant].

There are reports on the antioxidant activity of natural extracts in vegetable oil during storage. Methanolic extract of garlic at the concentrations of 250,500 , and $1000 \mathrm{ppm}$ were effective to protect sunflower oil (Test in oven at $65^{\circ} \mathrm{C}$, for 24 days) against oxidation, but the extract at concentration of $1000 \mathrm{ppm}$ proved to be more effective (IQBAL; BHANGER, 2007). Anwar et al. (2007) reported that moringa oleifera leaves hydromethanolic extract $(80 \%)$, at the concentration of $600 \mathrm{ppm}$, was very effective in retarding the peroxidation of sunflower oil stored at room temperature for 60 days. The addition of rice bran extract $\left(600 \mathrm{mg} \cdot \mathrm{kg}^{-1}\right)$, rosemary extract (200-500 ppm), and blackcurrant seed extract (3000 $\mathrm{ppm}$ ) were also effective in retarding the peroxide formation in sunflower oil (CHATHA et al., 2006; SAMOTYJA; MALECKA, 2007). Suja et al. (2004) reported that the addition of different concentrations of the methanolic extract of the sesame cake extracts $(5,10,50$, and $100 \mathrm{ppm})$ protected the refined vegetable oil (soybean, sunflower, and safflower oil) against oxidation (oven test at $60{ }^{\circ} \mathrm{C}$, for 15 days). The protection offered by the sesame cake extract is comparable with, or in some cases better than, synthetic antioxidant BHT, demonstrating that sesame cake extract could be used as a substitute for synthetic antioxidant. Ethanolic rosemary extracts $\left(500 \mathrm{mg} \cdot \mathrm{kg}^{-1}\right)$ and oregano extracts $\left(1000 \mathrm{mg} \cdot \mathrm{kg}^{-1}\right)$ were effective in retarding the oxidation of soybean oil incubated in an oven at $63{ }^{\circ} \mathrm{C}$; however these 
extracts were not as effective as the TBHQ (ALMEIDA-DORIA; REGITANO-D'ARCE, 2000).

\section{Conjugated dienes}

The determination of conjugated dienes is a good measure of the oxidative state of oils and thus a good indicator of effectiveness of antioxidants (IQBAL; BHANGER, 2007). Figure 2 shows that there was a progressive increase in the contents of conjugated dienes in all samples. However, the rate of increase in the samples with the addition of hydroethanolic and hydromethanolic extract was slow compared to that of the control sample. Highest contents were observed in the control sample, indicating greater intensity of oxidation, followed by samples with the addition of ascorbic acid, BHT, and hydroacetone extract. Hydroethanolic and hydromethanolic extracts activity at day 7 of the test was estatistically higher than that of the hydroacetone extract and synthetic antioxidants (ascorbic acid and BHT). There was no difference between all extracts antioxidant activity on the subsequent days.

The effectiveness of different natural sources in stabilizing vegetable oils during accelerated storage has been previously studied. Iqbal and Bhanger (2007) reported that garlic methanolic extract is a potent antioxidant for the stabilization of sunflower oil. The lowest content of conjugated dienes and thus the highest oxidation protection was reached with

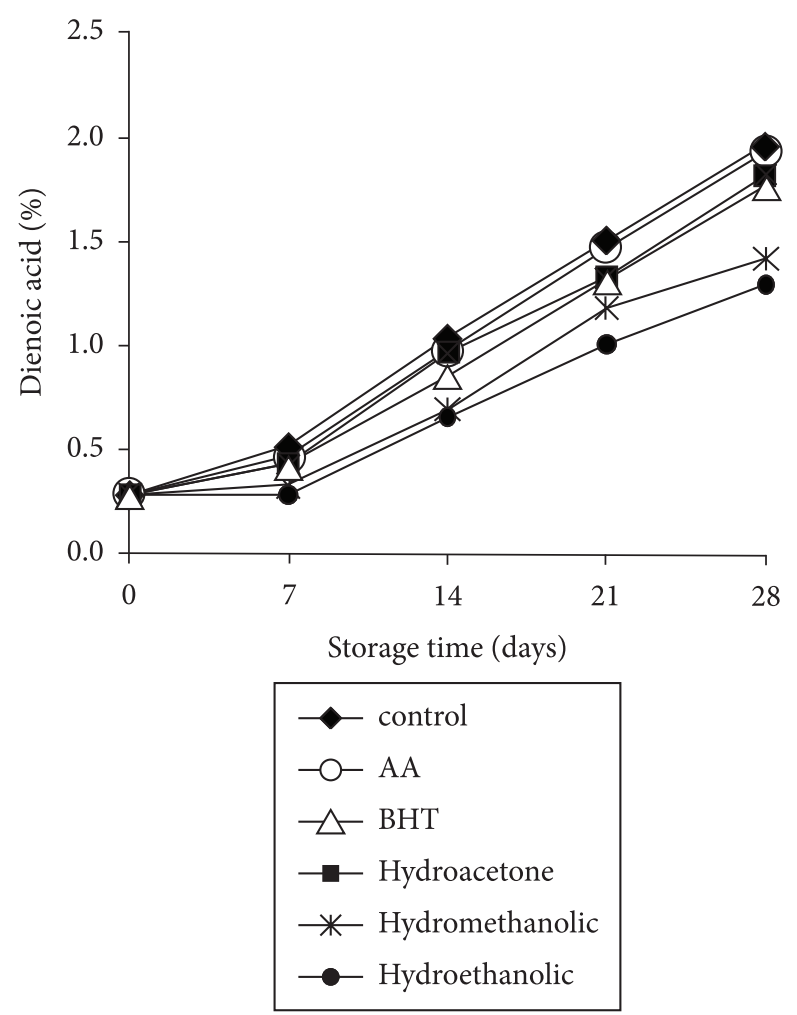

Figure 2. The effect of the addition of acerola fruit agro-industrial waste extract (200 ppm - total phenolic) on the formation of conjugated dienes (\% of dienoic acid) in soybean oil stored at $60^{\circ} \mathrm{C}$. [AA: ascorbic acid; BHT: butylated hydroxyl toluene; control samples: without antioxidant].
1000 ppm garlic extract. Coriander extract at a concentration of $1.600 \mathrm{mg} \cdot \mathrm{kg}^{-1}$ inhibited the oxidation process in sunflower oil, but the activity was more effective when the coriander extract was associated with the synthetic antioxidant and ascorbil palmitate (ANGELO; JORGE, 2008). Sunflower oil treated with Moringa oleifera hydromethanolic extracts (80\%) at a concentration of $600 \mathrm{ppm}$ showed the least content of conjugated dienes and thus reflected antioxidant efficacy of the extract (ANWAR et al., 2007).

\section{Conclusions}

The agro-industrial acerola fruit waste showed high concentration of total phenolic, whose extracts exhibited strong antioxidant capacity. Although the hydroacetone extract provided the reaction with the highest total phenolic content, the antioxidant action of this extract was smaller than the antioxidant action shown by hydroethanolic and hydromethanolic extracts, which exhibited the best antioxidant activity under the same experimental conditions, Therefore, agro-industrial acerola fruit waste can be considered a potential antioxidant source of natural origin.

\section{Acknowledgements}

The authors are grateful for the financial support provided by CNPq (Edital MCT/CNPq 15/2007-Universal).

\section{References}

ALMEIDA-DORIA, R. F.; REGITANO-D'ARCE, M. A. B. Antioxidant activity of rosemary and oregano ethanol extracts in soybean oil under thermal oxidation. Ciência e Tecnologia de Alimentos, v. 20, n. 2, p. 197-203, 2000.

ALOTHMAN, M.; BHAT, R.; KARIM, A. A. Antioxidant capacity and phenolic content of selected tropical fruits from Malaysia, extracted with different solvents. Food Chemistry, v. 115, n. 3, p. 785-788, 2009. http://dx.doi.org/10.1016/j.foodchem.2008.12.005

ANGELO, P. M.; JORGE, N. Avaliação do óleo de girassol adicionado de antioxidantes sob estocagem. Ciência e Tecnologia de Alimentos, v. 28, n. 2, p. 498-502, 2008.

ANWAR, F. et al. Stabilization of sunflower oil with moringa oleifera leaves under ambient storage. Journal of food lipids, v. 14, n. 1, p. 35-49, 2007. http://dx.doi.org/10.1111/j.1745-4522.2006.00069.x

AMERICAN OIL CHEMISTS' SOCIETY - AOCS. Official methods and recommended practices of the American Oil Chemists Society. 5th ed. Champaign: AOCS, 2006.

BRAND-WILLIAMS, W.; CUVELIER, M. E.; BERSET, C. Use of free radical method to evaluate antioxidant activity. Lebensmittel Wissenschaft und Techonologie, v. 28, n. 1, p. 25-30, 1995.

CATANEO, C. B. et al. Atividade antioxidante e conteúdo fenólico do resíduo agroindustrial da produção de vinho. Semina: Ciências Agrárias, v. 29, n. 1, p. 93-102, 2008.

CHATHA, S. A. S. et al. Antioxidant activity of different solvent extracts of rice bran at accelerated storage of sunflower oil. Journal of Food Lipids, v. 13 , n. 5, p. 424-433, 2006. http://dx.doi.org/10.1111/ j.1745-4522.2006.00068.x

CHEN, H-M. et al. Antioxidant activity of designed peptides based on the antioxidative peptide isolated from digests of a soybean 
Protein. Journal of Agricultural and Food Chemistry, v. 44, n. 9, p. 2619-2623, 1996. http://dx.doi.org/10.1021/jf950833m

GUO, C. et al. Antioxidant activities of peel, pulp and seed fractions of common fruits as determined by FRAP assay. Nutrition Research, v. 23, n. 12, p. 1719-1726, 2003. http://dx.doi.org/10.1016/j. nutres.2003.08.005

IQBAL, S.; BHANGER, M. I. Stabilization of sunflower oil by garlic extract during accelerated storage. Food Chemistry, v. 100, n. 1, p. 246-254, 2007. http://dx.doi.org/10.1016/j.foodchem.2005.09.049

JAYAPRAKASHA, G. K.; SINGH, R. P.; SAKARIAH, K. K. Antioxidant activity of grape seed (Vitis vinifera) extracts on peroxidation models in vitro. Food Chemistry, v. 73, n. 3, p. 285-290, 2001. http://dx.doi.org/10.1016/S0308-8146(00)00298-3

KRING, U.; BERGER, R.G. Antioxidant activity of some roasted foods. Journal Food Chemistry, v.72. n. 2 p. 223-229, 2001.

LIU, Q.; YAO, H. Antioxidant activities of barley seeds extracts. Food Chemistry, v. 102, n. 3, p. 732-737, 2007. http://dx.doi. org/10.1016/j.foodchem.2006.06.051

MAKRIS, D. P.; BOSKOU, G.; ANDRIKOPOULOS, N. K. Recovery of antioxidant phenolics from white vinification solid by-products employing water/ethanol mixtures. Bioresource Technology, v. 98, n. 15, p. 2963-2967, 2007. PMid:17110101. http://dx.doi. org/10.1016/j.biortech.2006.10.003

MALECKA, M. Antioxidant properties of the unsaponifiable matter isolated from tomato seeds, oat grains and wheat germ oil. Food Chemistry, v. 79, n. 3, p. 327-332, 2002. http://dx.doi.org/10.1016/ S0308-8146(02)00152-8

NACZK, M.; SHAHIDI, F. Phenolics in cereals, fruits and vegetables: Occurrence, extraction and analysis. Journal of Pharmaceutical and Biomedical Analysis, v. 41, n. 5, p. 1523-1542, 2006. PMid:16753277. http://dx.doi.org/10.1016/j.jpba.2006.04.002

OKONOGI, S. et al. Comparison of antioxidant capacities and cytotoxicities of certain fruit peels. Food Chemistry, v. 103, n. 3, p. 839-846, 2007. http://dx.doi.org/10.1016/j.foodchem.2006.09.034

OLIVEIRA, A. C. et al. Total phenolic content and free radical scavenging activities of methanolic extract powders of tropical fruit residues, Food Chemistry, v. 115, n. 2, p. 469-475, 2009. http:// dx.doi.org/10.1016/j.foodchem.2008.12.045

RE, R. et al. Antioxidant activity applying an improved ABTS radical cation decolorization assay. Free Radical Biology and Medicine, v. 26, n. 9-10, p. 1231-1237, 1999. http://dx.doi.org/10.1016/S08915849(98)00315-3

RIBEIRO, S. M. R. et al. Phenolic compounds and antioxidant capacity of Brazilian mango (Mangifera indica L.) varieties. Food Chemistry, v. 110, n. 3, p. $620-626,2008$. http://dx.doi.org/10.1016/j. foodchem.2008.02.067

ROESLER, R. et al. Atividade antioxidante de frutas do cerrado. Ciência e Tecnologia de Alimentos, v. 27, n. 1, p. 53-60, 2007.

SAMOTYJA, U.; MALECKA, M. Effects of blackcurrant seeds and rosemary extracts on oxidative stability of bulk and emulsified lipid substrates. Food Chemistry, v. 104, n. 1, p. 317-323, 2007. http:// dx.doi.org/10.1016/j.foodchem.2006.11.046

SÁNCHEZ-MORENO, C.; LARRAURI, J. A.; SAURA-CALIXTO, F. A procedure to measure the antiradical efficiency of polyphenols. Journal of the Science of Food and Agriculture, v. 76, n. 2, p. 270-276, 1998. http://dx.doi.org/10.1002/(SICI)10970010(199802)76:2\%3C270::AID-JSFA945\%3E3.0.CO;2-9

SCHMIDT, S. et al. Antioxidant activity of evening primrose phenolics in sunflower and rapeseed oils. European Journal of Lipid Science and Technology, v. 105 , n. 8 , p. 427-435, 2003. http://dx.doi. org/10.1002/ejlt.200300842

SOONG, Y-Y.; BARLOW, P. Antioxidant activity and phenolic content of selected fruit seeds. Food Chemistry, v. 88, n. 3, p. 411-417, 2004. http://dx.doi.org/10.1016/j.foodchem.2004.02.003

SUJA, K. J. et al. Antioxidant efficacy of sesame cake extract in vegetable oil protection. Food Chemistry, v. 84, n. 3, p. 393-400, 2004. http:// dx.doi.org/10.1016/S0308-8146(03)00248-6

WETTASINGHE, M.; SHAHIDI, F. Evening primrose meal: a source of natural antioxidants and scavenger of hydrogen peroxide and oxygen-derived free radicals. Journal of Agricultural and Food Chemistry, v. 47, n. 5, p. 1801-1812, 1999. PMid:10552455. http:// dx.doi.org/10.1021/jf9810416

YILDIRIM, A.; MAVI, A.; KARA, A. A. Determination of antioxidant and antimicrobial activities of Rumex crispus L. extracts. Journal of agriculture and Food Chemistry, v. 49, n. 8, p. 4083-4089, 2001. http://dx.doi.org/10.1021/jf0103572 